\title{
Persepsi Guru Terhadap Proses Pengawasan oleh Kepala Sekolah di SMK Negeri Se-Kota Solok
}

\author{
Fitri Andriani ${ }^{1}$, Nellitawati ${ }^{2}$, Elizar Ramli ${ }^{3}$ \\ ${ }^{123}$ Universitas Negeri Padang \\ $\supseteqq$ e-mail: fitri@fitri.com
}

\begin{abstract}
The purpose of this research was look information on the teacher perception about controlling of the headmaster on vocation senior high school. This is a descriptive research. The population is 201 teacher and research sample is 72 teachers who taken by simple random sampling. The instrument of this research was a questionnaire with Likert scale models that had tested for validity and reliability. Data analyzed using the average (mean) formula. The results of this research show teacher perception about controlling of headmaster on vocation senior high school (SMKN) in Solok city stay in good category with an average score 3,61 become 72,21 percent.
\end{abstract}

Keyword: controlling

Copyright (C) 2018 IICET (Indonesia) - All Rights Reserved

Indonesian Institute for Counseling, Education and Therapy (IICET)

\section{PENDAHULUAN}

Sekolah merupakan lembaga pendidikan formal yang membantu menghantarkan bangsa Indonesia untuk mencapai tujuan pendidikan nasional (Gunawan, H., 2012). Sekolah juga merupakan organisasi yang berada di bawah manajemen dengan tujuan untuk membantu menciptakan kondisi yang efektif di sekolah tersebut. Manajemen merupakan sekumpulan kegiatan perencanaan (Anthony, R. N., Govindarajan, V., \& Dearden, J., 2007; Nugroho, R., \& Wrihatnolo, R., 2011), pengorganisasian (Mahdia, F., \& Noviyanto, F. (2013), penggerakan dan pengawasan (Efendy, M., 2010; Winarna, J., \& Murni, S., 2006) yang dilakukan untuk mencapai tujuan organisasi dengan memberdayakan sumber daya manusia. Sementara manajemen sekolah berkaitan dengan kelancaran fungsi sekolah secara menyeluruh. Kepala Sekolah dalam organisasi sekolah merupakan pimpinan yang bertanggungjawab atas kelangsungan organisasi tersebut (Setiyati, S., 2014; Nellitawati, N., \& Boon, Y. B., 2015; Nuchiyah, N., 2007; Karweti, E., 2010; Triyanto, E., Anitah, S., \& Suryani, N., 2013). Salah satu elemen penting yang turut menentukan tercapainya tujuan dari keseluruhan kegiatan dalam manajemen pendidikan pada sekolah adalah pengawasan.

Sekolah merupakan suatu organisasi pendidikan yang dipimpin oleh kepala sekolah (Nellitawati, N., 2012). Kepala sekolah inilah yang nantinya akan melakukan pengawasan terhadap semua kegiatan sekolah. Pengawasan yang dilakukan oleh kepala sekolah diharapkan dapat meminimalisir terjadinya penyimpangan atau kesalahan dalam pelaksanaan tugas oleh guru yang dapat menimbulkan stress (Taufik, T., \& Ifdil, I., 2013; Wardi, R., \& Ifdil, I., 2016). Sebagaimana menurut Engkoswara (2011:219) pengawasan adalah proses untuk mengetahui ada tidaknya penyimpangan dalam pelaksanaan rencana agar segera dilakukan upaya perbaikan sehingga dapat memastikan bahwa aktivitas yang dilaksanakan secara ril merupakan aktivitas yang sesuai dengan apa yang direncanakan. 
Adapun indikator dari proses pengawasan yaitu : (a) penetapan standar pelaksanaan dimana standar mengandung arti sebagai suatu satuan pengukuran yang dapat digunakan sebagai patokan untuk penilaian hasil-hasil atau ukuran untuk mencapai tujuan, sasaran, dan target pelaksanaan(b) pemantauan, kegiatan monitoring/ pemantauan dan pengawasan adalah kegitan untuk mengumpulkan data tentang menyelenggarakan suatu kerja sama antara guru, kepala sekolah, konselor, supervisor, dan petugas sekolah lainnya dalam institusi satuan pendidikan (c) evaluasi adalah suatu kegiatan yakni mengukur dan menilai (d) tindak lanjut, maksudnya tidak hanya mengungkap penyimpangan tetapi juga penyediaan alternatif perbaikan, dan menentukan tindakan perbaikan (Engkoswara \& Komariah, 2011:220; Sule \& Saefullah, 2013:321; Handoko, 2000:363; Sagala, 2009:60; Daryanto, 2008:6)

Penelitian ini dilakukan berdasarkan pengamatan awal pada kepala sekolah di SMK Negeri Se-Kota Solok, yang masih memperlihatkan adanya kendala pada proses pengawasan yang belum dapat sesuai dengan yang diharapkan. Hal ini dilihat dari fenomena, seperti: (1) Kepala sekolah belum melaksanakan pemantauan kinerja guru secara maksimal. Hal ini terlihat karena masih adanya guru yang tidak berada dalam kelas saat proses belajar mengajar berlangsung. (2) Kepala sekolah belum melaksanakan pemantauan secara maksimal terhadap keaktifan guru. Hal ini terlihat karena masih adanya guru yang tidak ikut serta dalam pelaksanaan upacara bendera, kegiatan senam dan hari - hari besar Nasional. (3) Kepala sekolah jarang melakukan penilaian terhadap perangkat pembelajaran guru. Hal ini terlihat karena masih ada guru yang melakukan proses belajar mengajar dengan menggunakan perangkat pembelajaran tahun sebelumnya, dan ada sebagian guru yang dalam proses belalar mengajar tidak berpedoman pada RPP yang berlaku. (4) Kepala sekolah kurang memberikan tindak lanjut yang tegas kepada guru yang membuat kesalahan dalam pelaksanaan tugasnya. Hal ini terlihat karena adanya guru yang sering terlambat masuk kelas, guru meninggalkan kelas untuk keperluan pribadi .

Berdasarkan uraian diatas, penelitian ini dirancang untuk mengungkap persepsi guru terhadap proses pengawasan oleh kepala sekolah di SMK Negeri Se Kota Solok. Penelitian ini penting dilakukan agar kepala sekolah memahami apa yang menjadi kebutuhan dan diperlukan guru dalam pengajaran.

\section{METODE}

Jenis penelitian yang digunakan adalah deskriptif kuantitatif. Dengan populasi seluruh guru PNS pada SMKN di Kota Solok bejumlah 201 orang. Sampel penelitian 72 ditentukan menggunakan rumus Slovin. Instrumen penelitian yang digunakan berupa angket dalam bentuk skala Likert dengan lima alternatif jawaban yang telah melalui validitas dan reliabilitas. Validitas angket ditentukan dengan rumus tata jenjang Spearman. Kemudian dalam pengolahan angket digunakan rumus persentase.

\section{HASIL}

Hasil penelitian yang didapatkan menunjukkan bahwa persepsi guru terhadap proses pengawasan oleh kepala sekolah di SMK Negeri Se Kota Solok yang ditinjau dari empat indikator pengawasan.

Persepsi guru terhadap proses pengawasan oleh kepala sekolah dalam hal penetapan standar pelaksanaan kegiatan secara keseluruhan memperoleh skor rata-rata 3,70 tingkat capaian 73,96\% dengan kriteria baik, skor rata-rata tertinggi 4,14 tingkat capaian tertinggi 82,78\% dengan kriteria baik. Data tersebut berada pada item nomor 1 dengan pernyataan kepala sekolah menetapkan standar pelaksanaan kegiatan. Sedangkan skor ratarata terendah 3,40 tingkat capaian 68,06\% dengan kriteria cukup baik. Data tersebut berada pada item nomor 7 dengan pernyataan kepala sekolah menjelaskan prosedur kerja yang harus dilakukan.

Persepsi guru terhadap proses pengawasan oleh kepala sekolah dalam hal pelaksanaan pemantauan memperoleh skor rata-rata 3,82 tingkat capaian 76,36\% dengan kriteria baik. Skor rata-rata tertinggi 4,14 tingkat capian 82,78\% dengan kriteria baik. Data tersebut berada pada item nomor 9, dengan pernyataan kepala sekolah memantau kedisiplinan bapak/ibu dalam melaksanakan tugas. Sedangkan skor rata-rata terendah 3,11 tingkat capaian 62,22\% dengan kriteria cukup. Data tersebut berada item nomor 7 dengan pernyataan kepala sekolah memantau keikutsertaan bapak/ibu dalam mengikuti kegiatan rutin sekolah. 
Persepsi guru terhadap proses pengawasan oleh kepala sekolah dalam hal evaluasi memperoleh skor rata-rata 3,61 tingkat capaian 72,14\% dengan kriteria baik. Skor rata-rata tertinggi 4,01 tingkat capaian $80,28 \%$ dengan kriteria baik. Berada pada item nomor 1 dengan pernyataan kepala sekolah menilai apakah pelaksanaan pembelajaran di susun sudah sesuai dengan yang diharapkan. Sedangkan skor rata-rata terendah 2,76 tingkat capaian 55,28\% dengan kriteria cukup. Berada pada item nomor 10 dengan pernyataan kepala sekolah melakukan penilaian terus menerus.

Persepsi guru terhadap proses pengawasan oleh kepala sekolah dalam hal tindak lanjut memperoleh skor rata-rata 3,32 tingkat capaian 66,37\% dengan kriteria cukup. Skor rata-rata tertinggi 3,88 tingkat capaian $77,50 \%$ dengan kriteria baik. Data tersebut terdapat pada item nomor 9 dengan penyataan kepala sekolah memberikan pujian secara langsung terhadap pekerjaan yang bapak/ibu lakukan. Sedangkan Skor rata-rata terendah 2,86 tingkat capaian 57,22\% dengan kriteria cukup. Data tersebut berada pada item nomor 7 dengan kepala sekolah memberikan saran kepada bapak/ibu untuk memperbaiki hal-hal yang dinilai kurang tepat dalam pelaksanaan tugas.

Rekapitulasi data hasil penelitian mengenai persepsi guru terhadap proses pengawasan oleh kepala sekolah di SMK Negeri Se Kota Solok disajikan dalam tabel 1

Tabel 1. Rekapitulasi Skor Rata-rata Persepsi guru terhadap proses pengawasan oleh kepala sekolah di SMK Negeri Se Kota Solok disajikan dalam tabel 1.

\begin{tabular}{llccc}
\hline No & Proses Pengawasan & Rata-Rata & \% Ketercapaian & Kriteria \\
\hline $\mathbf{1}$ & Penetapan Standar & 3.7 & 73.96 & Baik \\
$\mathbf{2}$ & Pemantauan & 3.82 & 76.36 & Baik \\
$\mathbf{3}$ & Evaluasi & 3.61 & 72.14 & Baik \\
$\mathbf{4}$ & Tindak Lanjut & 3.32 & 66.21 & Baik \\
& Rata-Rata & $\mathbf{3 . 6 1}$ & $\mathbf{7 2 . 2 1}$ & \\
\hline
\end{tabular}

Berdasarkan tabel diatas diinformasikan bahwa persepsi guru terhadap proses pengawasan oleh kepala sekolah di SMK Negeri Se Kota Solok memperoleh skor rata-rata 3,61 tingkat capaian 72,21\% dengan kriteria baik.

Hasil penelitian menunjukan bahwa bahwa persepsi guru terhadap proses pengawasan oleh kepala sekolah di SMK Negeri Se Kota Solok memperoleh skor rata-rata 3,61 tingkat capaian 72,21\% dengan kriteria baik.

\section{PEMBAHASAN}

Hasil penelitian menunjukan bahwa persepsi guru terhadap proses pengawasan oleh kepala sekolah di SMK Negeri Se Kota Solok dilihat dari aspek penetapan standar memiliki skor 3,70 dengan tingkat pencapaian 76,36\% dan berada pada kategori baik. Skor tertinggi dalam aspek penetapan standar yaitu 4,14 dengan tingkat pencapaian $82,78 \%$ berada pada kategori baik yang pernyataannya yaitu kepala sekolah menetapkan standar pelaksanaan kegiatan yang akan bapak/ibu lakukan. Hal yang menyebabkan penetapan standar pelaksanaan kegiatan oleh kepala sekolah sudah baik adalah karena kepala sekolah telah menetapkan kriteria yang rasional dan objektif dalam pelaksanaan kegiatan. Sedangkan skor terendah yaitu 3,40 dengan tingkat pencapaian 68,06\% berada pada kategori cukup yang pernyataannya yaitu kepala sekolah menjelaskan prosedur kerja yang harus di lakukan dalam pelaksanaan tugas. Hal yang menyebabkan prosedur kerja yang harus di lakukan dalam pelaksanaan tugas berada pada skor terendah yaitu kurangnya komunikasi yang terjadi antara kepala sekolah dan guru . Upaya yang dapat dilakukan oleh kepala sekolah untuk mengatasi masalah 
tersebut hendaknya kepala sekolah melakukan pendekatan dan meningkatkan komunikasi dengan guru serta menjelasksan prosedur kerja guru sehingga rencana yang telah ditetapkan dapat berjalan dengan baik.

Hasil penelitian menunjukan bahwa persepsi guru terhadap proses pengawasan ditinjau dari hal pemantauan pada umumnya sudah cukup terlaksana dengan skor rata-rata 3,82 dan tingkat pencapaian 76,36\% berada pada kategori baik . Pada aspek ini yang menunjukan skor rata-rata tertinggi yaitu 4,14 dengan tingkat pencapaian $82,78 \%$ berada pada kategori baik dimana pernyataannya adalah kepala sekolah memantau kedisiplinan bapak/ibu dalam melaksanakan tugas. Sedangkan skor rata-rata terendah yaitu 3,11 dengan tingkat pencapaian $62,22 \%$ berada pada kategori cukup baik dimana pernyataannya adalah kepala sekolah memantau keikutsertaan bapak/ibu dalam mengikuti kegiatan rutin disekolah. Artinya pemantauan terhadap keikutsertaan guru dalam kegiatan rutin disekolah masih bisa dikatakan belum begitu baik. Belum optimalnya pemantauan yang dilakukan oleh kepala sekolah terhadap keikutsertaan guru menunjukkan bahwa kepala sekolah perlu meningkatkan lagi kegiatan pemantauan terhadap keikutsertaan guru dalam kegiatan rutin disekolah maka akan memperkecil kemungkinan kegagalan dalam mencapai hasil pekerjaan yang maksimal. Upaya yang dapat dilakukan untuk mengatasi permasalahan diatas adalah kepala sekolah perlu membagi dan meuangkan waktu dari sekian banyak kegiatan yang dilakukan setiap hari untuk melakukan pemantauan terhadap keiukutsertaan guru dalam kegiatan rutin disekolah.

Hasil penelitian menunjukan bahwa Persepsi guru terhadap proses pengawasan oleh kepala sekolah di SMK Negeri Se Kota Solok dari aspek evaluasi memiliki skor 3,61 dengan tingkat pencapaian 72,14\% dan berada pada kategori baik. Ini berarti bahwa evaluasi yang telah dilakukan oleh kepala sekolah sudah berjalan dengan baik di SMK Negeri Se Kota Solok. Menurut Syahril dkk (2009:115) evaluasi adalah (1) memperoleh dasar pertimbangan untuk menentukan keberhasilan pekerjaan, (2) menjamin cara kerja yang efektif dan efisien, (3) memperoleh fakta tentang kesulitan-kesulitan dan menghindarkan situasi yang dapat merusak pencapaian tujuan, (4) menyiapkan kesanggupan para guru dan orang tua mengembangkan organisasi sekolah. Berdasarkan hasil penelitian persepsi guru terhadap proses pengawasan oleh kepala sekolah pada aspek evaluasi dapat dilihat bahwa skor tertinggi 4,01 dengan tingkat pencapaian 80,28\% berada pada kategori baik yang mana pernyataannya yaitu kepala sekolah menilai apakah pelaksanaan pembelajaran yang bapak/ibu susun sudah sesuai dengan yang diharapkan. Sedangkan skor terendah yaitu 2,76 dengan tingkat pencapaian55,28\% berada pada kategori cukup terdapat pada pernyataan kepala sekolah melakukan penilaian secara terus menerus. Kepala sekolah yang tidak teratur dalam melakukan penilaian terhadap pekerjaan yang dilakukan oleh guru mungkin dikarenakan kepala sekolah kurang memiliki waktu yang tepat dalam melakukan penilaian terhadap pelaksanaan pekerjaan guru selain itu dikarenakan kurangnya kemampuan kepala sekolah dalam melakukan penilaian tersebut.

Hasil penelitian menunjukan persepsi guru terhadap proses pengawasan oleh kepala sekolah dilihat dari segi tindak lanjut pengawasan sudah cukup terlaksana dengan skor rata-rata 3,32 dengan tingkat pencapaian $66,37 \%$ yang berada pada kategori cukup. Pada aspek tindak lanjut ini menunjuk an sskor rata-rata tertinggi 3,88 dengan tingkat pencapaian $77,50 \%$ berada pada kategori baik dimana pernyataanya yaitu kepala sekolah memberikan pujian secara langsung terhadap pekerjaan yang bapak/ibu lakukan sesuai dengan kriteria yang telah ditetapkan. sedangkan skor rata-rata terendah 2,86 dengan tingkat pencapaian $57,22 \%$ berada pada kategori cukup dimana pernyataanya yaitu kepala sekolah memberikan saran kepada bapak/ibu untuk memperbaiki hal-hal yang dinilai kurang tepat. Hal yang menyebabkan proses pengawasan pada SMK Negeri Se Kota Solok ditinjau dari tindak lanjut masih berada pada kategori cukup karena kepala sekolah belum memberikan saran atau arahan serta bimbingan secara maksimal kepada guru dalam menindaklanjuti hambatan yang dihadapi guru dalam melaksanakan tugas. Dalam mengatasi masalah ini hendaknya kepala sekolah harus meberikan bantuan dan saran kepada guru agar pekerjaan yang dilakukan tersebut dapat terlaksana dengan maksimal. Sejalan dengan yang dikemukakan Handoko (2012:363) menyatakan bahwa " di dalam melakukan pengawasan yang terpenting adalah tindak lanjut dari pengawasan yang telah dilakukan, sehingga orang-orang yang diawasi benar-benar merasakan tujuan dan manfaat dari pengawasan yang telah ditetapkan." tindak lanjut disini tidak hanya berupa hukuman, tetapi juga seperti pembinaan maupun penghargaan yang diberikan kepada seseorang yang berprestasi dalam melaksanakan tugasnya. 


\section{CONCLUSION}

Ada beberapa kesimpulan yang dapat di peroleh, yaitu: 1) pada umumnya proses penetapan standar yang dilakukan oleh Kepala Sekolah Menengah Kejuruan dirasakan sudah terlaksana dengan baik; 2) pada umumnya proses pemantauan yang dilakukan oleh Kepala Sekolah Menengah Kejuruan dirasakan sudah terlaksana dengan baik; 3) pada umumnya proses evaluasi yang dilakukan oleh Kepala Sekolah Menengah Kejuruan dirasakan sudah terlaksana dengan baik; 4) pada umumnya proses tindak lanjut yang dilakukan oleh Kepala Sekolah Menengah Kejuruan dirasakan sudah terlaksana dengan cukup baik.

\section{REFERENCES}

Anthony, R. N., Govindarajan, V., \& Dearden, J. (2007). Management control systems (Vol. 12). New York, NY: McGraw-Hill.

Daryanto. (2008). Evaluasi Pendidikan. Jakarta: Rineka Cipta.

Efendy, M. (2010). Pengaruh Kompetensi, Independensi, dan Motivasi Terhadap Kualitas Audit Aparat Inspektorat Dalam Pengawasan Keuangan Daerah (Studi Empiris Pada Pemerintah Kota Gorontalo) (Doctoral dissertation, UNIVERSITAS DIPONEGORO).

Engkoswara dan Aan Komariah. (2011). Administrasi Pendidikan. Bandung: Alfabeta.

Fattah, Nanang. (2011). Landasan Manajemen Pendidikan. Bandung: PT Remaja Rosdakarya.

Gunawan, H. (2012). Pendidikan Karakter. Bandung: Alfabeta.

Handoko, Hani T. (2000). Manajemen Edisi 2. Yogyakarta: BPFE.

Karweti, E. (2010). Pengaruh kemampuan manajerial kepala sekolah dan faktor yang mempengaruhi motivasi kerja terhadap kinerja guru SLB di Kabupaten Subang. Jurnal Penelitian Pendidikan, 11(2), 77-89.

Mahdia, F., \& Noviyanto, F. (2013). Pemanfaatan Google Maps API Untuk Pembangunan Sistem Informasi Manajemen Bantuan Logistik Pasca Bencana Alam Berbasis Mobile Web (Studi Kasus: Badan Penanggulangan Bencana Daerah Kota Yogyakarta). Jurnal Sarjana Teknik Informatika, 1(1).

Nellitawati, N. (2012). Kontribusi Pengawasan Kepala Sekolah Terhadap Disiplin Kerja Guru SMA Negeri Di Kecamatan Koto Tangah Padang. Pedagogi: Jurnal Ilmu Pendidikan, 12(2), 24-31.

Nellitawati, N., \& Boon, Y. B. (2015). Hubungan Peranan Kepemimpinan Kepala Sekolah dengan Kompetensi Pedagogik Guru di SMK Negeri 2 Kota Padang. Pedagogi: Jurnal Ilmu Pendidikan, $15(2), 112-117$.

Nuchiyah, N. (2007). Pengaruh Kepemimpinan Kepala Sekolah dan Kinerja Mengajar Guru Terhadap Prestasi Belajar Siswa. Jurnal Pendidikan Dasar, 5(7), 1-4.

Nugroho, R., \& Wrihatnolo, R. (2011). Manajemen Perencanaan Pembangunan. Kompas Gramedia, Jakarta.

Sagala, Syaiful. (2009). Administrasi Pendidikan Kontemporer. Bandung: Alfabeta.

Setiyati, S. (2014). Pengaruh kepemimpinan kepala sekolah, motivasi Kerja, dan budaya sekolah terhadap kinerja guru. Jurnal Pendidikan Teknologi dan Kejuruan, 22(2), 200-206.

Sule, Enie Tisnawati dan Kurniawan Saefullah. 2013. Pengantar Manajemen. Jakarta: Prenada Media.

Syahril dan Asmidir Ilyas, dkk. (2009). Profesi Kependidikan. Padang: UNP Press.

Taufik, T., \& Ifdil, I. (2013). Kondisi Stres Akademik Siswa SMA Negeri di Kota Padang. Jurnal Konseling dan Pendidikan, 1(2), 143-150.

Triyanto, E., Anitah, S., \& Suryani, N. (2013). Peran Kepemimpinan Kepala Sekolah dalam Pemanfaatan Media Pembelajaran Sebagai Upaya Peningkatan Kualitas Proses Pembelajaran. Teknologi Pendidikan, 1(2), 226-238.

Wardi, R., \& Ifdil, I. (2016). Stress Conditions in Students Completing Thesis. GUIDENA: Jurnal Ilmu Pendidikan, Psikologi, Bimbingan dan Konseling, 6(2), 190-194.

Winarna, J., \& Murni, S. (2006). Pengaruh Personal Background, Political Background dan Pengetahuan Dewan tentang Anggaran terhadap Peran DPRD dalam Pengawasan Keuangan Daerah. Simposium Nasional Akuntansi X. 